\title{
An experimental study on the pathophysiology of rectal prolapse
}

Wafi Attaallah' $(\mathbb{D})$, Göksel Menek ${ }^{1}(\mathbb{D})$, Fatma Aleyna Erdaş ${ }^{1}(\mathbb{D})$, ibrahim Yusuf inceoğlu $(\mathbb{D})$, Makbule Pervin Kankılıç $(\mathbb{D}$, Ahmet Hakan Yılmazer' (D), Berrak Yeğen²(D)

1 Department of General Surgery, Marmara University Faculty of Medicine, Istanbul, Turkey

2 Department of Physiology, Marmara University Faculty of Medicine, Istanbul, Turkey

\section{ABSTRACT}

Objective: For decades, rectal prolapse has been hypothesized to be caused due to laxity or weakness of the pelvic floor muscles which is often supposed to be related to childbearing in females. However, $50 \%$ of females with rectal prolapse have been reported to be nulliparous and this hypothesis does not explain the incidence of rectal prolapse in males. The aim of this study was to evaluate the role of rectal redundancy in rectal prolapse pathophysiology.

Material and Methods: Nineteen female Sprague Dawley rats (250-300 g) at 16 weeks of age were obtained from the animal center. Rats were divided into two groups as rectal mobilization (study) group $(n=9)$ and sham-operated control $(n=10)$ group. In the study group, soft dissection was applied and rectum were mobilized up from the pelvic floor to create a redundant or hypermobilized rectum. The primary outcome was the rate of rectal prolapse after rectal mobilization.

Results: As compared to the sham-operated control group, in which none of the rats had rectal prolapse throughout the post-surgical period, rectal prolapse was observed in four of the rats in the rectal mobilization group ( $0 \%$ vs. $44 \% ; p=0.006)$. Being unable to increase the length of the rectums of the rats, but using only mobilization to create the redundancy, and the lack of data regarding any adhesions after surgery are the main limitations of this study.

Conclusion: This study showed the role of rectal redundancy on the rectal prolapse pathophysiology.

Keywords: Rectal prolapse, pathophysiology, redundancy

Cite this article as: Attaallah W, Menek G, Erdaş FA, Inceoğlu IY, Kankılıç MP, Yılmazer AH, et al. An experimental study on the pathophysiology of rectal prolapse. Turk J Surg 2021; 37 (2): 151-155.

\section{Corresponding Author}

Wafi Attaallah

E-mail: drwafi2003@yahoo.com

Received: 06.01.2021

Accepted: 02.04.2021

Available Online Date: 30.06 .2021

○ Copyright 2021 by Turkish Surgical Society Available online at www.turkjsurg.com

DOI: $10.47717 /$ turkjsurg.2021.5188

\section{INTRODUCTION}

Although rectal prolapse affects relatively few people (2.5 cases/100,000 people) and is very rarely life-threatening, symptoms can be debilitating if left untreated $(1,2)$. Rectal prolapse is generally more common in elderly women, but it may occur at any age and in either sex. While a number of factors have been shown to be associated with the development rectal prolapse, there is no clear cut "cause" of rectal prolapse. Chronic constipation is present in 30-67\% of patients, while an additional 15\% experience diarrhea. Some have assumed that the development of rectal prolapse is a consequence of multiple vaginal deliveries (1). Other risk factors of prolapse include long-term diarrhea, long-term straining during defecation, previous surgery, cystic fibrosis, chronic obstructive pulmonary disease, whooping cough, multiple sclerosis, and paralysis (3). However, the precise cause of rectal prolapse is still unknown (4-6). Few theories have been proposed regarding the pathophysiology of rectal prolapse. For decades, rectal prolapse has been hypothesized to be caused due to laxity or weakness of the pelvic floor muscles (7). Although the development of pelvic floor laxity in females is often supposed to be related to childbearing, $50 \%$ of females with rectal prolapse have been reported to be nulliparous (8). Furthermore, this hypothesis does not explain the incidence of rectal prolapse in males. On the other hand, rectal prolapse has also been suggested to be associated with psychiatric disorders $(1,2)$.

We recently suggested a novel hypothesis to explain the pathophysiology of rectal prolapse (9). Our suggestion is that the etiology behind rectal prolapse lies in the 
rectal anatomy itself rather than in an intrinsic dysfunction of the pelvic floor muscles. We believe that the pelvic floor weakness may not be fully responsible of rectal prolapse, but an anatomic variation of a redundant rectum in some individuals may predispose for rectal prolapse. In support of our hypothesis, we used a virtual simulator to demonstrate the process of rectal prolapse (Video 1) and explained this theory by an illustration showing the possible mechanism of rectal prolapse (Figure 1). In order to evaluate this hypothesis in an in vivo model, we also designed an animal study. Thus, the aim of this experimental study was to evaluate the role of rectal redundancy in rectal prolapse pathophysiology by observing the occurrence of rectal prolapse in response to rectal mobilization.

\section{MATERIAL and METHODS}

\section{Animals}

Female Sprague Dawley rats (250-300 g) at 16 weeks of age were obtained from the Marmara University Animal Center and were housed in cages (one rat/cage) and maintained in an air-conditioned room with controlled humidity (65-70\%), temperature $\left(22 \pm 2^{\circ} \mathrm{C}\right)$ and 12 -h light-dark cycles. Rats were fed with commercial rat chow and received tap water ad libitum. All the experimental protocols used in this study were approved by the Marmara University Animal Ethical Committee.

\section{Surgery and Experimental Design}

Rats were divided into two groups as rectal mobilization group $(n=9)$ and sham-operated control $(n=10)$ group. Under general anesthesia induced by intraperitoneal (i.p.) injection of ketamine (100 mg/kg) and xylazine (10 mg/kg), laparotomy was performed by transverse incision of the shaved lower abdomen. In the rectal mobilization group, soft dissection was applied using a mosquito clamp and rectum were mobilized up (by cutting the ligaments) from the pelvic wall to create a redundant or hypermobilized rectum (Figure 2). Circumferential dissection was performed along the rectum up to pelvic floor in the rectal mobilization group. The dissection was stopped at the pelvic floor. To prevent adhesions, hyaluronic acid gel was then applied to whole areas of dissection and along the rectum. In the sham-operated control group, laparotomy was performed without any dissections. Anti-adhesive material was not applied to the sham group since no any dissection was done and the rectum already fixed by its peritoneal ligaments. Abdominal incisions in both groups were closed by simple continuous sutures and subcutaneous saline ( $1 \mathrm{ml} / \mathrm{kg}$; i.p) was injected to prevent any fluid loss.

After a two-week recovery period, rats in both groups were given loperamide hydrochlorid $(0.15 \mathrm{mg} / \mathrm{kg} /$ day; Ali Raif Illaç, İstanbul) in their drinking water in order to induce constipation and thereby, straining during defecation. During the follow-up period, rats were checked every day, on two occasions, by lifting their tails and observing the anal openings during defecation. It was recorded as "complete prolapse" when the entire layer of the rectum with its visible concentric folds has protruded to the outside of the anus. At the end of the post-surgical 15. week, rats were sacrificed by decapitation. The primary outcome of this study was the rate of rectal prolapsed after rectal mobilization.

\section{Statistical Analysis}

Data were analyzed using the Statistical Package for Social Sciences for Windows version 23 (SPSS Inc.; Chicago, IL, USA). Analysis was performed using Chi-square test and $p$ values $<0.05$ were considered statistically significant.
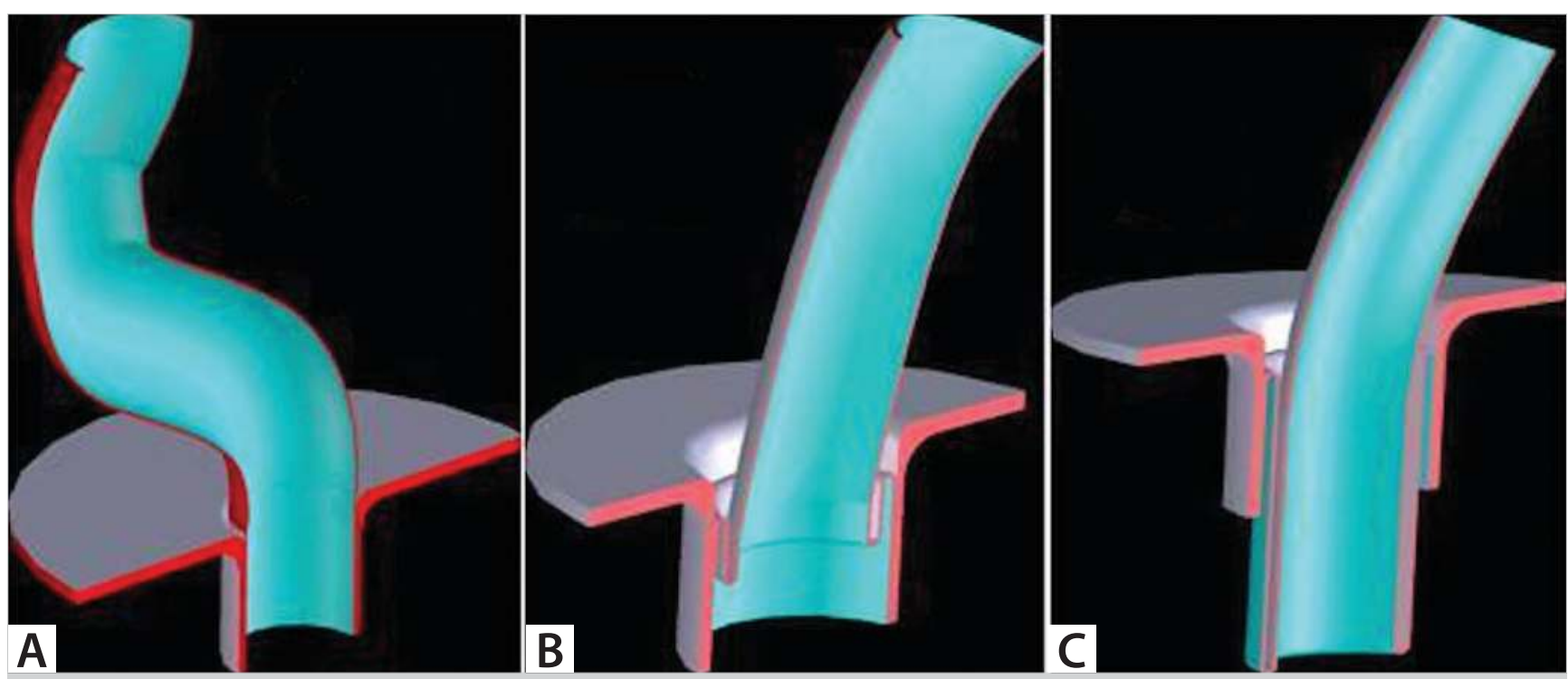

Figure 1. An illustration showing the possible mechanism of rectal prolapsed. A. A redundant rectum, B. Intussusception during straining, C. Complete prolapse. 


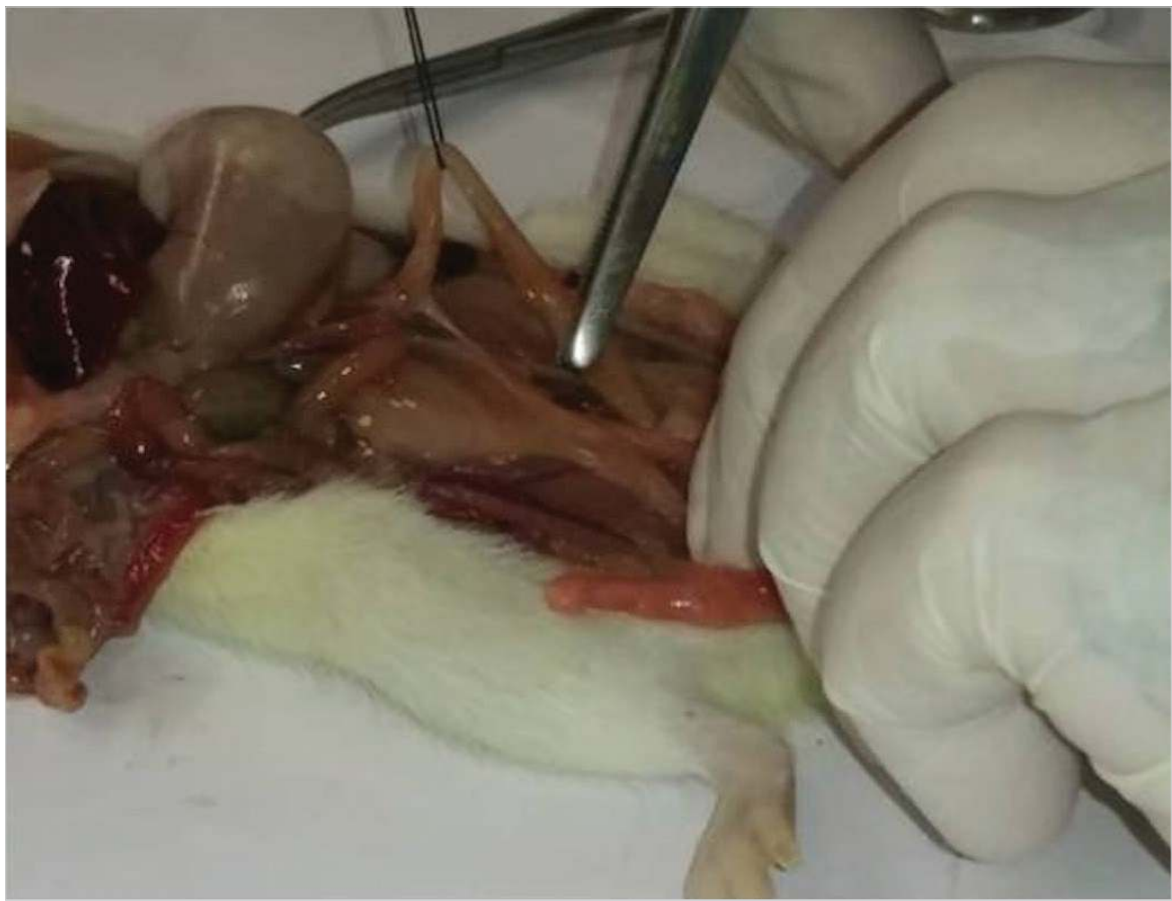

Figure 2. Rectum were mobilized up (by cutting the ligaments) from the pelvic wall to create a redundant or hypermobilized rectum.

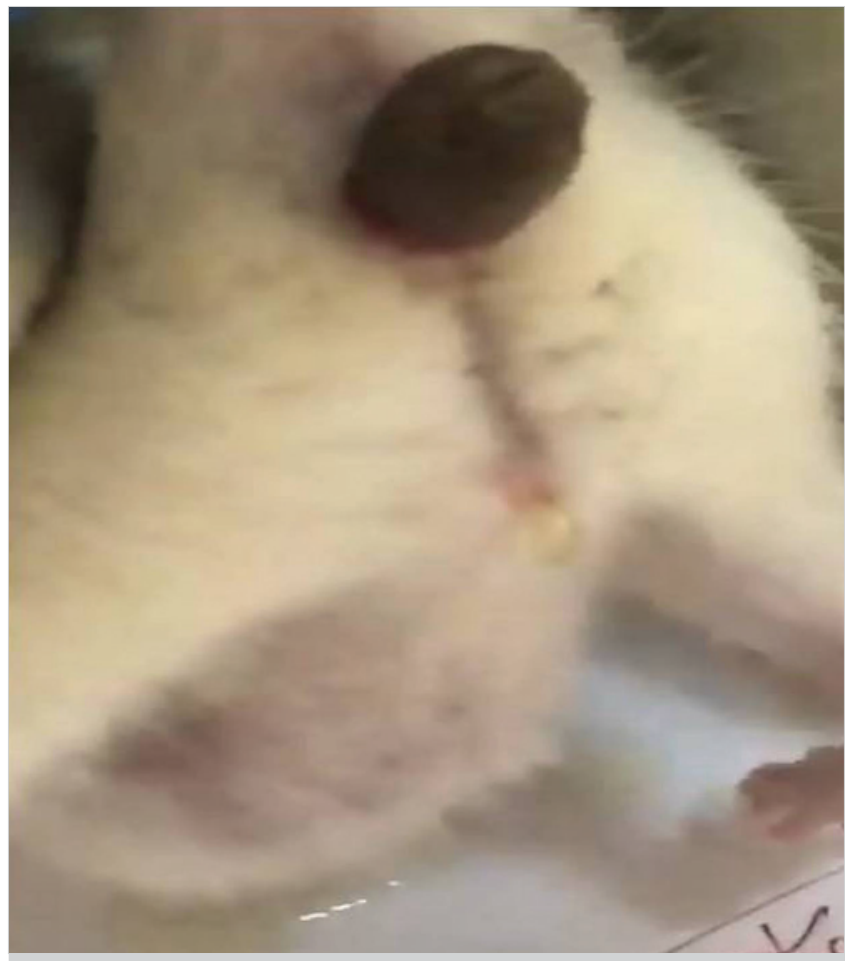

Figure 3. Rectal prolapses during defecation.

\section{RESULTS}

All the rats in both groups survived during the follow-up period. As compared to the sham-operated control group, in which none of the rats had rectal prolapse throughout the post-surgical period, rectal prolapse was observed in 4 of the rats in the rectal mobilization group ( $0 \%$ vs. $44 \%$; $p=0.006$ ). Rectal prolapses in these rats were initially observed at the 3, 6, 7 and 12 weeks following surgery and recurrent prolapses were consistently observed in these rats throughout the follow-up period (Figure 3). The presence of sustained prolapses in these rats ruled out that the observed prolapses have not occurred coincidentally.

\section{DISCUSSION}

Today, the most relevant explanations of rectal prolapse are still controversial. These explanations include anatomic dispositions, such as pelvic floor laxity, and predisposing factors, such as multiparity; but none of them are sufficient to explain the mechanism of prolapse and the definite cause is still unknown (10). In order to search the pathophysiology of rectal prolapse we established an animal model. All rats were nulliparous, and were operated to mobilize their rectum (by cutting ligaments in laparotomy) and given a constipation-inducing drug to cause severe straining during defecation. Nearly half of the rats developed rectal prolapses throughout the experimental period. Since the rats were all nulliparous, results show that rectal prolapse cannot be solely associated with giving birth. Furthermore, we also showed that mobilization of the rectum can by itself lead to rectal prolapse in some of the rats, suggesting that elongated and freed rectum could protrude repetitively as a result of defecation effort due to constipation. Changes in the timings of prolapse could be attributed to possible variations in rectal lengths. Since not all of 
the rats that had constipation and mobilized elongated rectum have developed rectal prolapse, it may be suggested that other additional causative factors could be responsible in exaggerating the mobility of rectum. Since most patients with rectal prolapse have a long history of constipation (5), it is thought that prolonged, excessive and repetitive straining during defecation may predispose to rectal prolapse (4,6-10). However, we believe that rectal intussusceptions or prolapse lead to obstructive defecation which subsequently may be the cause of severe straining during defecation. In 1912, Moschcowitz has proposed that rectal prolapse was a sliding hernia through a deficient pelvic floor which the rectum herniates (11). This theory was based on the observation that a hernia sac of peritoneum from the Pouch of Douglas and rectal wall can be seen (2). Although this theory still seems valid, we do not think that the pelvic floor weakness could lead to rectal prolapse. For example, the weakness of the abdominal wall around colostomy leads to parastomal hernia but not to stoma prolapse. However, an elongated non-fixed bowel may cause stoma prolapse without any weakness of the abdominal wall. In the same way, we think that an anatomic variation of a redundant (elongated) rectum may predispose for rectal prolapse without weakness of pelvic floor. Another concept suggested that rectal prolapse was actually a circumferential $2^{\circ}$ or $3^{\circ}$ intussusception (12). Complete circumferential intussusception usually starts 6-8 cm from the anal verge but can continue through the anal canal (13). This seems to be more reasonable and partially appropriate with our theory. Furthermore, in our theory we have explained the cause of intussusceptions by the redundancy of the rectum. Surgery is the mainstay of rectal prolapse treatment. Until today over one hundred surgical modalities were identified. Transabdominal or Perineal procedures are performed to repair a rectal prolapse. Transabdominal repairs involve rectal fixation, rectal resection or a combination of resection and fixation. Attachment of the rectum to the sacrum can be performed using foreign material or sutures although the lateral rectal attachments can be achieved to the sacral periosteum without foreign material. Perineal procedures including Altemeier operation (perineal proctosigmoidectomy) and Delorme Procedure in which transanal resection of the rectum or rectal plication method is also used to shorten the length of rectum (13-17). As transabdominal repairs involve sacro-promontory fixation of the rectum without any intervention to the pelvic floor or muscles, giving us a hint that rectal prolapse may not be the result of a pelvic floor or muscle pathology. Thus, rectal prolapse etiology may lie within its mobile state. Being unable to increase the length of the rectums of the rats, but using only mobilization to create the redundancy, and the lack of data regarding any adhesions after surgery are the main limitations of this study. On the other hand, observation of the rats during defecation was done only twice a day, but a 24-h video monitoring could be used to gather more convincing results.
Since there are no similar studies and not enough knowledge in this field, this study introduced a new reasonable explanation on the pathophysiology of rectal prolapse and proved that using a new experimentally model of rectal prolapse, which may be a premise for future studies. We think that this theory has a significant value in clinical practice since the parity and pelvic floor weakness seem to be less important than the redundancy of the rectum. The redundancy is common and well-defined in the human colon; that is, an individual with a redundant coIon has an abnormally long colon, especially in the final section (the descending colon). A redundant colon often has additional loops or twists. Other names for a redundant colon include tortuous colon or elongated colon. We think that this definition can be applied to the rectum. Therefore, this variation of the rectum may lead to the clinic of obstructive defecation, which also includes the rectal prolapse. Furthermore, this diagnosis is usually underestimated, particularly in cases of internal intussusceptions. By using our hypothesis, in which we defined the variation of redundant rectum, we think that the prevalence of rectal prolapse among both genders should also be re-evaluated. Further studies including clinical studies are needed to definitely prove our theory in explaining the pathophysiology of rectal prolapse.

\section{CONCLUSION}

This study showed the role of rectal redundancy on rectal prolapse pathophysiology. We believe that the pelvic floor weakness may not be fully responsible of rectal prolapse, but an anatomic variation of a redundant rectum in some individuals may predispose for rectal prolapse.

Ethics Committee Approval: The approval for this study was obtained from Marmara University Animal Experiments Local Ethical Committee (Decision No: 08.2019.mar, Date: 08.02.2019).

Peer-review: Externally peer-reviewed.

Author Contributions: Concept - A.A., G.S.S., V.K.; Design - A.A., S.S., V.K.; Supervision - A.A., G.S.S., V.K.; Materials - D.J.A., O.H.S., V.B.; Data Collection and/ or Processing - D.J.A., O.H.S.; Analysis and/or Interpratation - D.J.A., O.H.S., V.B.; Literature Review - D.J.A., S.S., V.B.; Writing Manuscript - A.A., G.S.S., V.K.; Critical Reviews - A.A., G.S.S., S.S., V.K.

Conflict of Interest: The authors declare that they have no conflict of interest.

Financial Disclosure: The authors declared that this study has received no financial support.

\section{REFERENCES}

1. Mills S. Rectal prolapse. In:BeckDE, Roberts PL, Saclarides TJ, Senagore AJ, Stamos MJ, Wexner SD (eds). The ASCRS Manual of Colon and Rectal Surgery. $2^{\text {nd }}$ ed. New York: Springer; 2011. [CrossRef]

2. Varma M, Rafferty J, Buie WD. Practice parameters for the management of rectal prolapse. Dis Colon Rectum 2011; 54(11): 1339-46. [CrossRef] 
3. E-Medicine Health. Cunha JP. Rectal Prolapse. Available from: https:// www.emedicinehealth.com/rectal_prolapse/article_em.htm (Accessed date: 04.06.2020). [CrossRef]

4. American Society of Colon and Rectal Surgeons (ASCRS). ASCRS core subjects: Prolapse and Intussusception. Available from: https://fascrs. org/healthcare-providers/education/core-subjects?page $=4$ (Acces sed date: 04.06.2020). [CrossRef]

5. Baeten CG, Kuijipers, HC, Wolff BG, Beck DE, Church JM, Fleshman JW, et al. The ASCRS Textbook of Colon and Rectal Surgery. New York: Springer; 2007:674. [CrossRef]

6. Wexner SD, Zbar AP. Coloproctology. New York: Springer; 2010:143. [CrossRef]

7. Patcharatrakul T, Rao SSC. Update on the pathophysiology and management of anorectal disorders. Gut Liver 2018; 12(4): 375-84. [CrossRef]

8. Bordeianou L, Hicks CW, Kaiser AM, Alavi K, Sudan R, Wise PE. Rectal prolapse: an overview of clinical features, diagnosis, and patientspecific management strategies. J Gastrointest Surg 2014; 18(5): 105969. [CrossRef]

9. Attaallah W. Update on the pathophysiology of rectal prolapse. Turk J Gastroenterol 2019; 30(12): 1074-5. [CrossRef]

10. Karulf RE, Madoff RD, Goldberg SM. Rectal prolapse. Curr Probl Surg 2001: 38(10): 771-832. [CrossRef]
11. Moschcowitz AV. The pathogenesis, anatomy and cure of prolapse of the rectum. Surg Gynecol Obstet 1912; 15: 7-12. [CrossRef]

12. Monro A. The morbid anatomy of the human gullet, stomach, and intestines. Edinburgh: Archibald Constable, 1811;363. [CrossRef]

13. Broden G, Dolk A, Holmstrom B. Recovery of the internal anal sphincter following rectopexy: a possible explanation for continence improvement. Int J Colorectal Dis 1988; 3(1): 23-8. [CrossRef]

14. Varma M, Rafferty, Buie WD. Practice parameters for the management of rectal prolapse. Dis Colon Rectum 2011; 54(11): 1339-46. [CrossRef]

15. Tou S, Brown SR, Malik Al, Nelson RL. Surgery for complete rectal prolapse in adults. Cochrane Database Syst Rev 2008; 4: CD001758. [CrossRef]

16. Brown AJ, Anderson JH, McKee RF, Finlay IG. Strategy for selection of type of operation for rectal prolapse based on clinical criteria. Dis CoIon Rectum 2004; 47(1): 103-7. 758. [CrossRef]

17. Cutait D. Sacro-promontory fixation of the rectum for complete rectal prolapse. Proc R Soc Med 1959; 52: 105. [CrossRef]

18. Carter AE. Rectosacral suture fixation for complete rectal prolapsed in the elderly, the frail and the demented. Br J Surg 1983; 70(9): 522-3. [CrossRef]

\section{ORIJINAL ÇALIŞMA-ÖZET}

Turk J Surg 2021; 37 (2): 151-155

\section{Rektal prolapların patofizyolojisi üzerine deneysel bir çalışma}

Wafi Attaallah ${ }^{1}$, Göksel Menek ${ }^{1}$, Fatma Aleyna Erdaş ${ }^{1}$, Ibrahim Yusuf İnceoğlu ${ }^{1}$, Makbule Pervin Kankılıç ${ }^{1}$, Ahmet Hakan Yılmazer ${ }^{1}$, Berrak Yeğen ${ }^{2}$

${ }^{1}$ Marmara Üniversitesi Tıp Fakültesi, Genel Cerrahi Anabilim Dalı, İstanbul, Türkiye

${ }^{2}$ Marmara Üniversitesi Tıp Fakültesi, Fizyoloji Anabilim Dalı, İstanbul, Türkiye

\section{ÖZET}

Giriş ve Amaç: Yıllardır, rektal prolapsusun, genellikle kadınlarda çocuk doğurma ile ilgili olduğu düşünülen pelvik taban kaslarının gevşekliği veya zayıflığından kaynaklandığı varsayılmaktadır. Ancak rektal prolapsusu olan kadınların \%50'sinin nullipar olduğu bildirilmiştir ve bu hipotez erkeklerde rektal prolapsus etiyolojsini açıklamamaktadır. Bu çalışmanın amacı, rektal prolapsus patofizyolojisinde rektal fazlalığın rolünü değerlendirmektir.

Gereç ve Yöntem: Hayvan merkezinden 16 haftalık 19 dişi Sprague Dawley sıçanı (250-300 g) elde edildi. Sıçanlar, rektal mobilizasyon (çalışma) grubu $(n=9)$ ve kontrol $(n=10)$ grubu olarak iki gruba ayrıldı. Çalışma grubunda fazlalık veya hipermobilize bir rektum oluşturmak için yumuşak diseksiyon uygulandı ve rektum mobilize edildi. birinci çıkarım rektal mobilizasyon sonrası rektal prolapsus oranıydı.

Bulgular: Ameliyat sonrası dönem boyunca kontrol grubundaki sıçanların hiçbirinde rektal prolapsus görülmezken, mobilizasyon grubundaki sıçanların dördünde rektal prolaps gözlendi (\%0'a karşı \%44; $p=0,006$ ). Sıçanların rektumlarının uzunluğunu uzatamamak, sadece mobilizasyon kullanmak ve ameliyat sonrası herhangi bir yapışıklığa ilişkin veri eksikliği bu çalışmanın ana kısıtlamalarıdır.

Sonuç: Bu çalışma, rektal prolapsus patofizyolojisinde rektal redundancy'nin rolünü göstermiştir.

Anahtar Kelimeler: Rektal prolapsus, patofizyoloji, redundancy

Doi: $10.47717 /$ turkjsurg.2021.5188 